\title{
ANALISIS TEORI KEDATANGAN DAN PERKEMBANGAN ISLAM DI INDONESIA
}

\author{
Masruroh Lubis \\ STAI Sumatera Medan \\ masruroh_21@yahoo.co.id \\ Irwanto \\ STAI Serdang Lubuk Pakam \\ irwantospdi@gmail.com
}

\author{
Rasyid Anwar Dalimunthe \\ STAI Serdang Lubuk Pakam \\ rad577rad@gmail.com
}

\author{
Ruslan Efendi \\ STAI Aceh Tamiang \\ ruslanefendi420@gmail.com
}

\begin{abstract}
The urgency of discussing the arrival and development of Islam, especially for students of Islamic education, is certainly something that should not be missed. The purpose of this discussion is to make it easier for Indonesia to understand the strong sources of its arrival and those influencing its development. This article was conducted through a literature study from literature, books and the internet. Then conduct a study related to the discussion. The result was the entry of Islam into Indonesia where Arab traders brought Islam by sea. Third, while a strong candidate as the first location for the entry of Islam to Indonesia is the coast of Sumatra. The four developments of Islam in Indonesia that became the main actors were the da'i and ustadz, ulama and several Islamic kingdoms. Fifth, along with its development, the life of Sufism and Islamic institutions emerged, including mosques, pesantren, surau and dayah.
\end{abstract}

Keywords: Arrival, Development Of Islam, Analysis

\section{PENDAHULUAN}

Dalam pendidikan Islam tentu diajarkan berbagai macam benda-benda dan hal lainnya sehingga dengan itu semua menjadi jalan untuk memahami keberadaan Allah swt. ${ }^{1}$ Untuk menyiapkan generasi muda kedepannya tentu dengan pengajaran Islam nantinya diharapkan akan memiliki kepribadian yang spritual. ${ }^{2}$ Pendidikan selama ini lebih diorientasikan pada tiga pilar pendidikan, yaitu menambah pengetahuan, pembekalan keterampilan hidup (life

1 Rasyid Anwar Dalimunthe, "Hasil-Hasil Rumusan Internasional Wolrd Muslim Conference On Educationtentang Pendidikan Dalam Islam," Jurnal Asy-Syukriyyah 22, no. 1 (2021): 112-25, https://doi.org/10.36769/asy.v22i1.157.

${ }^{2}$ Asep Muljawan \& Saiful Ibad, "Pengembangan Karakter Spiritual Keagamaan Siswa Dalam Perspektif Islam,” Jurnal Asy-Syukriyyah 21, no. 1 (2020): 49-60, https://doi.org/10.36769/asy.v21i1.98. 
skill), dan menekankan cara menjadi “orang” sesuai dengan kerangka berfikir peserta didik. ${ }^{3}$ Kehadiran dan munculnya pendidikan Islam di bumi Indonesia sangat erat kaitannya dengan masuknya Islam di bumi pertiwi. ${ }^{4}$ Membicarakan kedatangan dan perkembangan Islam di Indonesia yang kejadiannya telah berlangsung lama tentu bukanlah pekerjaan mudah. Karena penting membuktikan secara nyata atau bisa dikatakan adanya temuan-temuan yang telah terukur oleh ahlinya sehingga bisa disebutkan tempat dan tanggal/bulan/tahun kejadiannya berlangsung. Namun tidak bisa dipungkiri banyak ahli yang ingin tahu tentang kedatangan dan perkembangan Islam di Indoensia itu berlangsung. Sehingga memunculkan temuan-temuan yang kadang berbeda atau bisa saja sama tentu memunculkan teori-teori yang beragam yang dapat dijadikan referensi-referensi dalam mengetahui kedatangan dan perkembangan Islam di Indoneisa bagi generasi saat ini.

Masuknya Islam ke Nusanatara ini tentu karena oleh para pedagang dan penceramah dengan damai. ${ }^{5}$ Islam datang ke Timur Tengah dari rahim tempat lahirnya, terutama Arab Saudi, kemudian menyebar ke seluruh penjuru dunia termasuk Nusantara Asia Tenggara.Ini merupakan proses transformasi agama dan peradaban yang mengesankan. Namun sebagai kajian sejarah, secara teoritis penyebaran ini telah menimbulkan kompleksitas tersendiri, terutama di daerah-daerah terpencil di luar pusat kelahirannya. Karena kompleksitas Islam, misalnya, proses datangnya Islam ke nusantara menjadi pengkajian teoritis yang baik dan menambah pengetahuan, misalnya, banyak sudut pandang di kalangan sejarawan menunjukkan bukti-bukti yang berbeda. Alasan perbedaan ini adalah fokus dari bukti yang diberikan berbeda. Beberapa menunjukkan asal waktu kedatangan, pengangkut dan dampak yang ditunjukkan. Perbedaan yang mencolok tentunya akan mempengaruhi kesimpulan ${ }^{6}$.

Selanjutnya penulis juga menyadari judul ini telah banyak di kupas oleh beberapa penulis baik berbentuk artikel lainnya. Adapun sebagian artikel-artikel yang penulis dapatkan seperti Fauziah Nasution dengan hasil yang menyampaiakan, ketika Islam masuk ke Indonesia, sekitar tahun 1963 proses masuknya Islam ke Indonesia merupakan kajian yang diminati secara terus menerus. Oleh karena itu, terus menerus ada pengkajian dalam rangka memperbaiki atau

3 Supriadi, "Islam Dan Relasi Sosial Pandangan Al-Qur'an Tentang Multikulturalisme," Jurnal AsySyukriyyah 18, no. 1 (2017): 101-31, https://doi.org/10.36769/asy.v18i1.74.

${ }^{4}$ muslim, "Pertumbuhan Insititusi Pendidikan Awal Di Indonesia :Pesantren, Surau Dan Dayah," Jurnal Bilqolam Pendidikan Islam 2, no. 1 (2021): 19-37, https://doi.org/10.51672/jbpi.v2i1.45.

5 Juli Iswanto, "Pertumbuhan Institusi Sosial Politik Samudera Pasai, Malaka, Banten Dan Mataram," Jurnal Bilqolam Pendidikan Islam 2, no. 1 (2021): 37-49, https://doi.org/10.51672/jbpi.v2i1.46.

${ }^{6}$ Moeflich Hasbullah, Islam dan Transformasi Masyarakat Nusantara (Jakarta: Kencana, 2017), h. 1 
memperkokoh kajian-kajian yang ada. Ulama merupakan peran sentral awal kedatangan dan kemajuan Islam di Indonesia. Cendekiawan Arab sebagai pengusaha adalah kelompok utama yang menjadi perantara Islam ke wilayah nusantara dan mengembangkannya, diikuti oleh para misionaris dari kelompok sufi yang ahli. Citra imam sufi erat kaitannya dengan dua citra: seorang pengusaha yang menyebarkan Islam melalui perniagaan dan titik pusat ekonomi rakyat, dan melalui kekuatan seorang sultan sambil menginformasikan agama Islam ${ }^{7}$. Begitu juga dengan artikel Latifa Annum Dalimunthe menyampaikan bahwa Ada tiga teori tentang masuknya Islam ke Indonesia: 1) Teori Gujarat Snouck, yang mengklaim bahwa Islam berasal dari Gujarat, didasarkan pada: a) kurangnya fakta untuk menjelaskan peran bangsa Arab dalam menyebarkan Islam ke Nusantara. ) Hubungan perdagangan India memiliki sejarah panjang. c) Prasasti Islam tertua di Sumatera menggambarkan hubungan antara Sumatera dan Gujarat. 2) Teori Mekah, Hamka mengumumkan masuknya Islam ke Indonesia pada abad pertama H/7. 3) Teorinya mempelajari budaya Persia dalam masyarakat Islam Indonesia mirip dengan Persia ${ }^{8}$. Selanjutnya artikel Husaini Husda menyampaikan proses Islamisasi di Indonesia berlangsung sangat rumit Kompleks dan panjang, ini juga berdasarkan berbagai teori. Penerimaan Islam oleh masyarakat adat secara bertahap telah mengintegrasikan Islam ke dalam tradisi, norma dan tatanan kehidupan sehari-hari masyarakat setempat. Hal ini menunjukkan bahwa orang Indonesia sangat mudah menerima nilai-nilai eksternal, dan ini juga merupakan bukti keterbukaan mereka. Sikap ini juga dibarengi dengan terbentuknya komunitas-komunitas muslim di wilayah pesisir yang semula merupakan tempat warga lokal berinteraksi dengan manca negara. ${ }^{9}$

Proses artikel ini dilakukan melalui penelitian literatur dari buku, artikel dan internet dan lainnya. Kemudian melakukan pengkajian terkait dengan pembahasan. Untuk membahas hasil artikel dijelaskan melalui deskripsi ke literatur-literatur yang ada. Kemudian menarik kesimpulan atas hasil pencarian berdasarkan tujuan artikel.

Beberapa artikel yang disampaikan oleh penulis, maka artikel ini mempunyai kelebihan tersendiri dari artikel-artikel yang dimaksud. Penulis dalam membuat judul artikel mengharapkan analisa terhadapa teori yang disampaiakan. Sehingga penulis yakin dan percaya

7 Fauziah Nasution, "Kedatangan dan Perkembangan Islam di Indonesia," Jurnal Dakwah dan Pengembangan Sosial Kemanusiaan 11, no. 1 (2020): 26-46, https://doi.org/10.32923/maw.v11i1.995.

8 Latifa Annum Dalimunthe, "Kajian Proses Islamisasi Di Indonesia," Jurnal Studi Agama dan Masyarakat 12, no. 1 (2016): 115-25, https://doi.org/10.23971/jsam.v12i1.467.

${ }^{9}$ Husaini Husda, "Islamisasi Nusantara (Analisis Terhadap Discursus Para Sejarawan)," Adabiya 18, no. 35 (2016): 17-29, https://doi.org/10.22373/adabiya.v18i35.1202. 
artikel ini memiliki keunikan yang tentunya nanti akan menstimulasi para penulis selanjutnya untuk ikut berpartisipasi dalam menganalisa teori-teori yang disampaikan. Dari uraian di atas penulis menawarkan 2 (dua) hal fokus masalah yang akan ditelaah secara serius yaitu Bagaimana Kedatangan dan Perkembangan Islam Di Indonesia dan Analisa Penulis terhadap Teori Kedatangan dan Perkembangan Islam Di Indonesia?. Selanjutnya tujuan dari pembahasan ini tentu ingin mengetahui kedatangan dan perkembangan Islam di Indonesia serta analisa penulis. Adapun yang menjadi implikasi dari pembahasan ini yaitu sebagai bahan bacaan yang ilmiah bagi para akademisi-akademisi yang sedang belajar dalam seputar kedatangan dan perkembangan islam di indonesia.

\section{METODE PENELITIAN}

Metode deskriptif digunakan dalam penelitian ini. Jenis penelitian ini adalah penelitian kepustakaan. Dalam penelusuran perpustakaan, yang mengambil data dari berbagai literatur terkait, untuk memperoleh data lainnya maka penulis juga menggunakan dokumentasi. Adapun literatur yang digunakan yaitu buku, jurnal dan google serta lainnya.

\section{PEMBAHASAN}

\section{Kedatangan Islam Ke Indonesia}

Teori India

Kebanyakan sarjana Belanda percaya bahwa kedatangan Islam datang dari India, termasuk Pijnappel dari Leiden University, J.P Moquette dan Snouck Hurgronje. Snouck Hurgronje meyakini bahwa abad ke-12 adalah masa yang paling mungkin untuk penyebaran Islam di Nusantara ${ }^{10}$. Pijnappel mengatakan bahwa orang Arab Syafi'i berimigrasi dan menetap di India, membawa Islam ke Nusantara. Dalam perkembangan selanjutnya, teori tersebut dikemukakan oleh Snouck Hurgronje, yang percaya bahwa meskipun Islam memiliki pengaruh yang kuat di kota-kota India Selatan, banyak Muslim Dhaka tinggal di sana dan bertindak sebagai perantara perdagangan antara Timur Tengah dan pulau-pulau. Mereka menyebarkan Islam ke Kepulauan Melayu pertama, dan kemudian orang-orang Arab. Namun, Snouck Hurgronje tidak secara spesifik menyebut wilayah India Selatan, karena menurutnya itu adalah asal mula Grand Slam Nusantara, namun ia menyebutkan bahwa itu terjadi pada abad ke-12. Ini adalah periode yang

${ }^{10}$ Haidar Putra Daulay, Sejarah Pertumbuhan dan Pembaruan Pendidikan Islam di Indonesia (Jakarta: Kencana, 2007), h. 13 
paling mungkin sejak Islam mulai menyebar di Nusantara. Snouck Hurgronje jarang menggunakan fakta untuk menyebut peran orang Arab dalam penyebaran Islam di Nusantara, sehingga ia menyimpulkan bahwa Islam di Nusantara tidak berasal dari Arabia. Di sisi lain, ia meyakini bahwa Islam berasal dari India karena hubungan perdagangan yang terjalin lama antara Nusantara dan India ${ }^{11}$.

Sarjana Belanda lainnya, Moquette, menyimpulkan bahwa asal muasal Islam di Nusantara adalah Gujarat. Mirip dengan nisan lain yang ditemukan di makam Maulana Malik Ibrahim (wafat 822/1419) di Gresik, Jawa Timur, sebenarnya bentuknya sama dengan nisan di Cambay, Gujarat. Berdasarkan contoh batu nisan tersebut, ia menyimpulkan bahwa batu nisan di Gujarat tidak hanya diproduksi untuk pasar lokal, tetapi juga digunakan untuk impor ke daerah lain, termasuk Sumatera dan Jawa. Selain itu dengan mendatangkan batu nisan dari Gujarat, masyarakat Nusantara juga menganut agama Islam dari sana.

Gambar 1. Makam Maulana Malik Ibrahim,1419 M

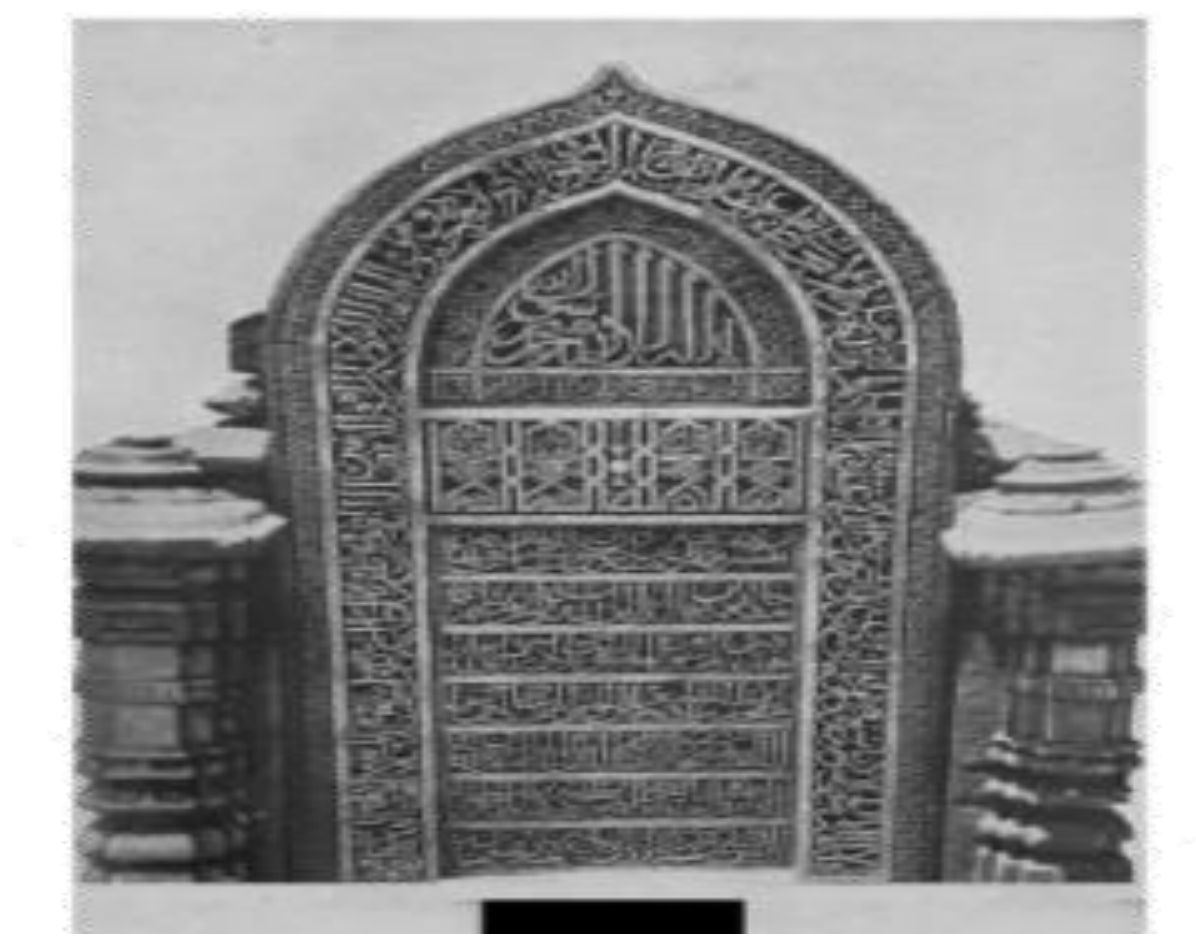

Teori Gujarat adalah asal muasal Islam di Nusantara dan terlihat memiliki kekurangankekurangan khusus. Misalnya, Marison membuktikan ini. Dia percaya bahwa meskipun Fatimi mengisyaratkan bahwa batu nisan yang ditemukan di beberapa bagian nusantara mungkin

11 Sarkawi B. Husaini, Sejarah Masyarakat Islam Indonesia (Surabaya: Airlangga University Press, 2017), h. 2 
berasal dari Gujarat atau Bangladesh, ini tidak berarti bahwa Islam juga diperkenalkan di sana. Marisson membantah teori ini dan menunjukkan bahwa selama Islamisasi Samudra Pasai (raja pertama meninggal pada 698/1297), Gujarat pada waktu itu masih kerajaan Hindu. Hanya setahun kemudian (699/1298), Cambe di Gujarat diperintah oleh Muslim. Ia mengatakan bahwa jika Gujarat adalah pusat Islam dan para penyebar Islam telah masuk ke Nusantara sejak saat itu, maka Islam akan berdiri dan berkembang di Gujarat sebelum kematian Malik Saleh. Itu didirikan dan dikembangkan di Gujarat sebelum 698/1297. ${ }^{12}$

Analisis penulis terhadap teori ini, memang bisa saja ada benarnya bahwa islam datang dari india bila mana kita meninjaunya dari segi perdagangan dan lalu lintas laut. Karena pedagang india juga aktif dalam hal mengunjungi nusantara sebagai objek perdagangan dan juga tempat yang tidak begitu jauh dari nusantara. Selain itu memang beberapa hal nama-nama ulama yang meningggal atau tempat dikebumikannya ulama tersebut terlihat ulama yang berasal dari india.

Teori Arab

Selain teori India, ada pula "teori Arab" yang meyakini bahwa Islam di Nusantara berasal dari bahasa Arab. Teori ini juga telah didukung oleh banyak sarjana, termasuk: Crawfurd, Niemann, dan pembela yang paling gigih adalah Naquib al-Attas ${ }^{13}$

Pandangan ini didasarkan pada kesamaan antara mazhab di Koromandel dan Malabar dengan mayoritas Muslim (yakni sekte Syafi'i) di Nusantara. Menurut Arnold, sejak awal abad Hijriah atau abad ketujuh dan kedelapan Masehi, pedagang Arab telah menduduki posisi dominan dalam perdagangan Islam Timur-Barat. Fakta-fakta dari Cina semakin menguatkan hipotesis ini bahwa pada akhir kuartal ketiga abad ke-7, para saudagar Arab telah menjadi pemimpin pemukiman Muslim Arab di sepanjang pantai Sumatra. Menurut laporan, beberapa dari mereka menikahi gadis-gadis lokal, sehingga menjadikan inti kumpulan Muslim yang terdiri dari imigran Arab dan penduduk lokal. Menurut Arnold, anggota komunitas Muslim juga melaksanakan aktivitas untuk menyebarkan Islam ${ }^{14}$

Pada seminar-seminar yang diadakan pada tahun 1969 dan 1978 tentang masuknya Islam ke Indonesia, mereka menyimpulkan bahwa Islam datang langsung dari Arab, bukan India. Bukan pada abad ke-12 atau ke-13, melainkan pada abad ke-1 Hijriah atau abad ke-7 Masehi.

\footnotetext{
12 Azyumardi Azra, Jaringan Ulama Timur Tengah \& Kepulauan Nusantara Abad XVII dan XVIII (Jakarta: Kencana, 2013), h. 3

${ }^{13}$ Haidar Putra Daulay, Pendidikan Islam di Indonesia: Historis dan Eksistensinya (Jakarta: Kencana, 2019), h. 20

${ }^{14}$ Husaini, Sejarah Masyarakat Islam Indonesia, h. 5
} 
Tidak sulit dipercaya bahwa Islam yang masuk ke Indonesia berasal dari Arab, atau lebih tepatnya, dari Hanzhi sebagai jalan tengah. Hal ini didasarkan pada latar belakang bahwa Rasulullah SAW lahir, besar, menerima wahyu dan menjalankan tugas rasulnya di Hanzhi. Untuk teori-teori Islam yang berasal dari Persia dan India, Hassan Asari tidak memungkiri keberadaan dan kontribusi kedua wilayah ini ketika proses pembangunan Indonesia tiba. Menurut dia, letak geografis Indonesia yang jauh di timur Arab, Proses sejarah masuknya Islam ke Indonesia mau tidak mau akan melibatkan dimensi spasial yang menghubungkan Indonesia dengan bangsa Arab. ${ }^{15}$

Analisis penulis dengan teori Arab yang mengatakan Islam datang dari negeri Arab tersebut merupakan yang tidak bisa dibantahkan. Selain penulis setuju dengan anggapan islam lahir dari negeri tersebut juga para masyarakat arab juga begitu meminati perdagangan ke beberapa wilayah termasuk indonesia. Dan beberapa penelitan yang menyimpulkan bahwa islam di bawa oleh pedagang arab pada abad ke 7 Masehi menjadi kekuatan tersendiri untuk meyakini dan menerima bahwa islam datangnya dari negeri Arab tersebut.

\section{Teori Persia}

Teori yang dikemukakan oleh Otoritas Nasional Palestina percaya bahwa Islam di Kepulauan Islam berasal dari Persia. Hoesein Djajadiningrat percaya bahwa Islam masuk ke Nusantara pada abad ke-13, dengan Samudra Pasai sebagai pusatnya. Argumentasinya didasarkan pada kesamaan budaya antara masyarakat Islam di Nusantara dan budaya Persia. Ahmad Mansyur Suryanegara mencontohkan empat kesamaan budaya antara Persia dan Islam di Nusantara. Pertama dari peristiwa 10 Muharram atau Asyura adalah untuk memperingati Syiah. Kedua, ada kesamaan ajaran antara tokoh sufi Iran al-Hallaj dan Syekh Siti Jenar. Muens juga mendukung teori Persia ini. Mons mengatakan bahwa pada masa dinasti Sasanian pada abad ke-5 M, banyak orang Persia yang berada di Aceh. Dia mengatakan bahwa kata "Pasai" berasal dari kata "Persia". Selain itu, Muns juga menyatakan bahwa ketika Ibnu Batutah datang ke Aceh, ada dua ulama dari Persia, yaitu Tadjuddin al-Syirazi dan Shiraz Jerman (Sayyid Syarif al-Ashbahani). ${ }^{16}$

Analisis penulis tentang teori ini sudah jelas tidak memungkinkan untuk mengatakan Islam pertama kali di bawa oleh orang persia. Tetapi kita tidak memungkiri beberapa hal yang menjadi aktivitas ibadah yang dilakukan oleh masyarakat muslim indonesia ada kemiripan

\footnotetext{
${ }^{15}$ Hasan Asari, Sejarah Pendidikan Islam (Medan: Perdana Publishing, 2018), h. 88

16 Ahmad Fakhri Hutauruk, Sejarah Indonesia: Masuknya Islam Hingga Kolonialisme (Medan: Yayasan Kita Menulis, 2020), h. 8
} 
dengan beberapa amalan yang dilakukan muslim persia. Karena abad ke 13 masehi yang disampaikan tentu menjadi kesimpulan bahwa masih ada negara lain (Arab pada abad ke 1 Masehi) yang lebih awal datang ke indonesia membawa islam.

Teori Cina

Pendapat mengatakan Islam di Nusantara adalah "teori Tionghoa" yang menyatakan karena saat abad ke-9 Masehi, beberapa Muslim Tionghoa di Guangzhou dan bagian Tiongkok selatan lainnya berdatangan ke Jawa, Kedah dan Sumatera. Evakuasi tersebut terjadi karena pada era tersebut, penduduk Provinsi Guangdong dan bagian lain China Selatan ditindas, dan mayoritas penduduk di daerah tersebut adalah Muslim. Dengan munculnya bukti-bukti peninggalan budaya, peran orang Tionghoa semakin terlihat jelas, yaitu adanya unsur Tionghoa pada bangunan berbagai masjid Jawa Kuno, seperti bagian atas Masjid Vantaa Banten yang berbentuk bulat ${ }^{17}$.

Gambar 2. Masjid Sendang Duwur Paciran Lamongan

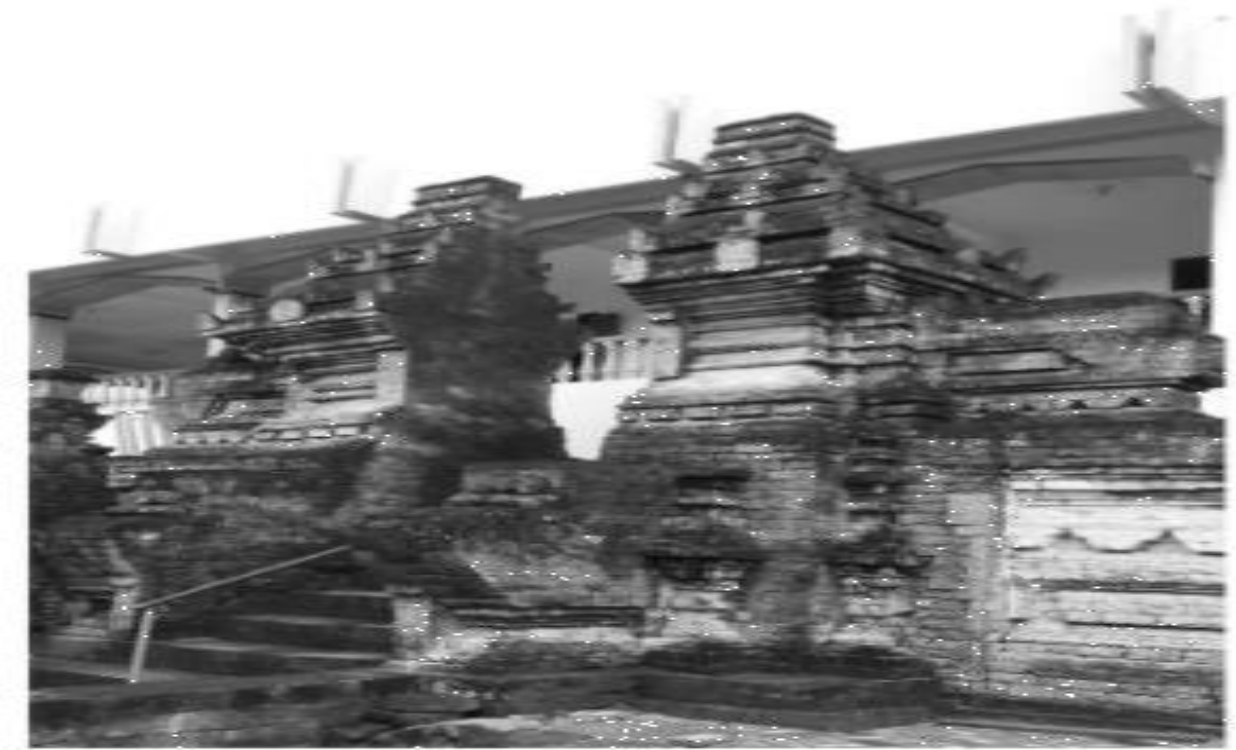

Namun, teori Cina tidak berbicara tentang awal masuknya Islam, tetapi peran yang dimainkan dalam pemberitaan tentang keberadaan komunitas Muslim di awal Nusantara, dan peran dalam Islamisasi pada abad ke-15 dan ke-16. Tiongkok memberikan banyak informasi sejarah bagi keberadaan komunitas Islam. Selain berita Arab, berita tentang keberadaan orang Arab dan Muslim di Nusantara di China pada abad ke-7 dan ke-8 juga pernah diberitakan. Ini menunjukkan bahwa Islam masih hidup di Cina, kecuali lebih dulu dari sebelumnya. Jika Masjid Wajinzi (komunitas) didirikan di Guangzhou pada abad ke-7, hanya makam (individu)

\footnotetext{
${ }^{17}$ Husaini, Sejarah Masyarakat Islam Indonesia, h. 9-10
} 
atau interaksi dengan perwakilan perdagangan yang akan ditemukan di Nusantara baru. Bahasa Tionghoa yang unik juga meningkatkan keberadaan dan fungsinya. Mudah dibaca.

Teori Tukri

Martin van Bruinessen mengajukan teori Islamisasi yang lain. Bruinessen mengungkapkan dalam dua karyanya bahwa selain Arab dan Tionghoa, Indonesia juga diislamkan oleh Kurdi Turki. Bruinessen melihat banyak data. Pertama berapa banyak Ulama Kurdi yang berperan dalam kursus Islam di pulau-pulau tersebut, dan buku-buku yang ditulis oleh para sarjana Kurdi telah menjadi sumber informasi yang berpengaruh. Buku Tanwir al-Qulub karya Muhammad Amin al-Kurdi sangat populer di kalangan Tarekat Naqsyabandi di Indonesia. Muhammad Amin adalah seorang ulama Kurdi. Kedua di antara para ulama di Madinah, Ibrahim al-Kurani pernah mengajar Ulama Indonesia dari Tarikat Syattariyah dan kemudian dibawa ke Nusantara. Ibrahim al-Kurani adalah seorang ulama Kurdi dan banyak muridnya adalah orang Indonesia. Ketiga dalam Islam, Syukuran dan tradisi lainnya, tradisi Barzanji yang populer di Indonesia dibacakan oleh setiap Maulid Nabi pada 12 Rabiul Awal. Bruinessen mengatakan bahwa Barzanji adalah seorang ulama yang berpengaruh di Kurdistan dan nama keluarga dari para syekh tarekat. Keempat bruinessen juga dikejutkan dengan istilah dan nama Kurdi yang sangat populer di Haji Kurdi, Jalan Kurdi, Gang Kurdi, di negara lain dan Indonesia ${ }^{18}$.

Gambar Peta Masuknya Islam Ke Indonesia

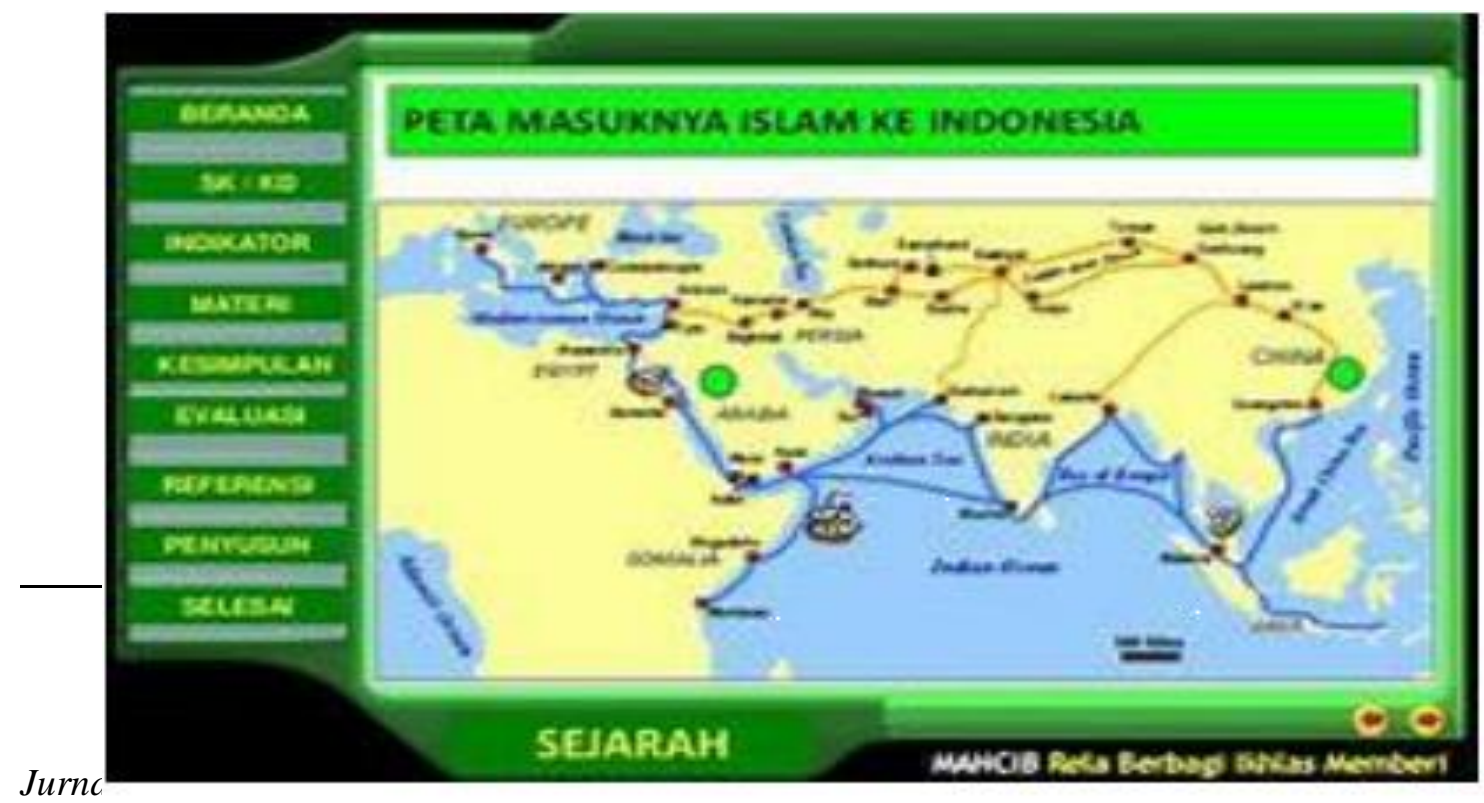




\section{Perkembangan Islam Di Indonesia}

Dalam perkembangan Islam, peran dakwah dan ustadz sangat penting. Dalam kurun waktu yang singkat, Islam berkembang di seluruh Indonesia. Dalam hal perkembangan Islam di Indonesia, ulama dan kerajaan Islam memiliki layanan yang sangat kaya, itulah sebabnya Islam telah menjadi agama di sebagian besar negara di Indonesia. Dalam perkembangan Islam di Indonesia didirikan lembaga-lembaga Islam seperti pendidikan, hukum, politik, dan ekonomi. Institusi pendidikan dimulai dengan pendirian masjid sebagai tempat ibadah dan pendidikan. Di masjid, anak-anak dan orang dewasa akan mengaji. Institusi pendidikan di luar masjid juga muncul di luar masjid, antara lain pesantren, dayah dan surau. Lembaga hukum Islam juga dibutuhkan, karena peran hukum Islam dalam masyarakat sangat penting. Berkaitan dengan hukum Islam, masyarakat perlu melakukan banyak hal, seperti nikah, warisan, sistem politik. Lahirnya kerajaan Islam: Pasai, Perlak, Aceh Darussalam di Sumatera Darussalam; Demak, Pajang Mataram, Banten dan Cirebon, serta berbagai pulau lainnya di Indonesia, Kalimantan, dan Sulawesi dan Maluku ${ }^{19}$.

Satu hal yang dapat diperdebatkan adalah bahwa Islam masuk ke Indonesia pada waktu yang berbeda, Islam telah memasuki wilayah tertentu sejak lama, dan ada juga wilayah yang mengalami kemunduran Islam. Dalam hal ini, sejarawan Islam sepakat bahwa Islam pertama kali masuk ke Indonesia di Sumatera. Sedangkan nisan di pemakaman Letima Fatima Bent Maimon (Letima), diduga merupakan saat Islam masuk ke Jawa.pada tahun 475 H (1082 M). Situasi politik mempercepat penyebaran Islam di pulau Jawa, ketika Majapahit dilemahkan oleh perselisihan. Bupati pesisir berhasil menyingkirkan pengaruh Raja Majapahit. Dengan Bupati pesisir yang beragama Islam, agama menjadi kekuatan baru dalam pembangunan masyarakat ${ }^{20}$. Kehidupan tasawuf juga makmur di Indonesia, bahkan ada yang beranggapan bahwa salah satu cara Islamisasi di Indonesia adalah melalui tasawuf. Dan kehidupan tasawuf telah bangkit di Indonesia, seperti: Hamzah Fansuri, Abdurrauf Assingkili, Burhunuddin Ulakan, dan kehidupan orang orang suci di Jawa ${ }^{21}$.

\footnotetext{
${ }^{19}$ Daulay, Pendidikan Islam di Indonesia: Historis dan Eksistensinya, h. 32

${ }^{20}$ Daulay, Sejarah Pertumbuhan dan Pembaruan Pendidikan Islam di Indonesia, h. 15

${ }^{21}$ Ibid
} 
Gambar 3. Peta Perkembangan Islam
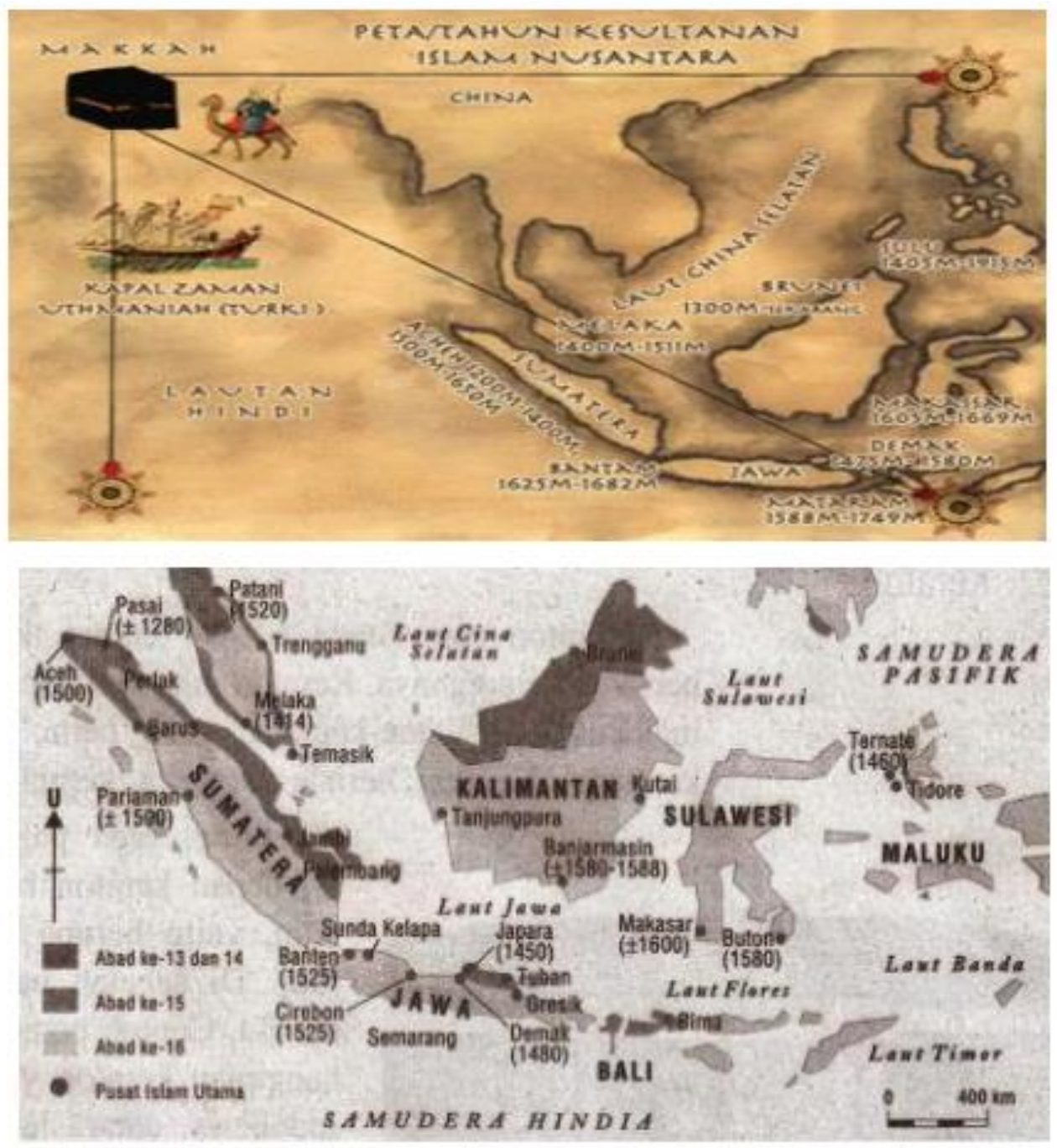

Seperti terlihat dari gambar di atas, Sumatera (Barus, Aceh dan Pasai) hadir ke Nusantara mulai abad ke-12 hingga ke-14, dan maju secara terus menerus sejak abad ke-15 hingga ke-16. Pada abad ke-14 (tahun 1450 M), Islam berkembang dari Aceh ke Jawa, yaitu Jepara, Tuban dan Gresik. Kemudian pada abad ke-15 1460, terus berkembang menjadi wilayah Ternate dan Tidore. Sepuluh tahun kemudian, Islam masuk ke wilayah Demark pada tahun 1480 dan maju secara terus menerus dengan hadirnya Kerajaan Demark pada tahun 1575-1580 M. Islam masuk ke Banten dan Serbia pada tahun yang sama (yaitu 1525 M atau abad ke-15 M). Dan Kalimantan; Islam Buton dan Banjarmasin muncul pada abad ke-16 (1580). Kerajaan Banjar didirikan pada tahun 1980 dan 1588, menandai perkembangan Islam di wilayah tersebut. Pada tahun yang sama Kerajaan Islam Banjar jatuh, Kerajaan Islam Mataram juga berdiri pada tahun 
1588-1749. Masuk dan berkembangnya Islam di Makassar terjadi pada awal abad ke-16, yaitu $1605-1669 .^{22}$

\section{KESIMPULAN}

Sesuai analisis penulis, maka kesimpulan yang dapat diambil dan disampaikan. Pertama seiring dengan banyaknya para ahli yang melakukan penelitian tentang kedatangan Islam ke Indonesia maka muncul beberapa teori seperti teori India, Arabia, Persia, Cina dan Turki. Kedua namun beberapa teori yang ada masih dapat dibantah secara ilmiah oleh ahli-ahli lain sehingga yang lebih condong dan kuat, kedatangan Islam ke Indonesia adalah teori Arabia. Dimana Pedagang Arablah yang membawa Islam ke Indonesia melalui pesisir laut. Ketiga sedangkan kandidat kuat sebagai lokasi pertama kali yang menjadi kedatangan Islam ke Indonesia adalah pesisir sumatera. Keempat perkembanga Islam di Indonesia yang menjadi aktor utamanya adalah para muballig dan ustadz, ulama dan beberapa kerajaan-kerajaan Islam. Kelima seiring dengan perkembangan maka muncullah kehidupan tasawuf dan lembaga islam antara lain masjid, pesantren, surau dan dayah. Selanjutnya muncullah institusi pendidikan, hukum, politik dan ekonomi.

\section{DAFTAR PUSTAKA}

Asari, Hasan. Sejarah Pendidikan Islam. Medan: Perdana Publishing, 2018.

Azra, Azyumardi. Jaringan Ulama Timur Tengah \& Kepulauan Nusantara Abad XVII dan XVIII. Jakarta: Kencana, 2013.

Dalimunthe, Latifa Annum. "Kajian Proses Islamisasi Di Indonesia." Jurnal Studi Agama dan Masyarakat 12, no. 1 (2016): 115-25. https://doi.org/10.23971/jsam.v12i1.467.

Dalimunthe, Rasyid Anwar. "Hasil-Hasil Rumusan Internasional Wolrd Muslim Conference On Educationtentang Pendidikan Dalam Islam.” Jurnal Asy-Syukriyyah 22, no. 1 (2021): 112-25. https://doi.org/10.36769/asy.v22i1.157.

Daulay, Haidar Putra. Pendidikan Islam di Indonesia: Historis dan Eksistensinya. Jakarta: Kencana, 2019.

- Sejarah Pertumbuhan dan Pembaruan Pendidikan Islam di Indonesia. Jakarta: Kencana, 2007.

Hasbullah, Moeflich. Islam dan Transformasi Masyarakat Nusantara. Jakarta: Kencana, 2017.

${ }^{22}$ Nasution, “Kedatangan dan Perkembangan Islam di Indonesia.”, h 26-46 
Husaini, Sarkawi B. Sejarah Masyarakat Islam Indonesia. Surabaya: Airlangga University Press, 2017.

Husda, Husaini. "Islamisasi Nusantara (Analisis Terhadap Discursus Para Sejarawan)." ADABIYA 18, no. 35 (2016): 17-29. https://doi.org/10.22373/adabiya.v18i35.1202.

Hutauruk, Ahmad Fakhri. Sejarah Indonesia: Masuknya Islam Hingga Kolonialisme. Medan: Yayasan Kita Menulis, 2020.

Ibad, Asep Muljawan \& Saiful. "Pengembangan Karakter Spiritual Keagamaan Siswa Dalam Perspektif Islam.” Jurnal Asy-Syukriyyah 21, no. 1 (2020): 49-60. https://doi.org/10.36769/asy.v21i1.98.

Iswanto, Juli. "Pertumbuhan Institusi Sosial Politik Samudera Pasai, Malaka, Banten Dan Mataram." Jurnal Bilqolam Pendidikan Islam 2, no. 1 (2021): 37-49. https://doi.org/10.51672/jbpi.v2i1.46.

Muslim. "Pertumbuhan Insititusi Pendidikan Awal Di Indonesia:Pesantren, Surau Dan Dayah.” Jurnal Bilqolam Pendidikan Islam 2, no. 1 (2021): 19-37. https://doi.org/10.51672/jbpi.v2i1.45.

Nasution, Fauziah. "Kedatangan dan Perkembangan Islam di Indonesia." Jurnal Dakwah dan Pengembangan Sosial Kemanusiaan 11, no. 1 (2020): 26-46. https://doi.org/10.32923/maw.v11i1.995.

Supriadi. “Islam Dan Relasi Sosial Pandangan Al-Qur'an Tentang Multikulturalisme.” Jurnal Asy-Syukriyyah 18, no. 1 (2017): 101-31. https://doi.org/10.36769/asy.v18i1.74. 